\title{
Review \\ The Immunometabolic Roles of Various Fatty Acids in Macrophages and Lymphocytes
}

\author{
Jose Cesar Rosa Neto ${ }^{1,2, *}$, Philip C. Calder ${ }^{3,4,5}{ }^{(D}$, Rui Curi ${ }^{6}$, Philip Newsholme ${ }^{7} \mathbb{D}$, Jaswinder K. Sethi ${ }^{3,4,5}$ \\ and Loreana S. Silveira ${ }^{1}$ (D)
}

check for updates

Citation: Rosa Neto, J.C.; Calder, P.C.; Curi, R.; Newsholme, P.; Sethi, J.K.; Silveira, L.S. The Immunometabolic Roles of Various Fatty Acids in Macrophages and Lymphocytes. Int. J. Mol. Sci. 2021, 22, 8460. https://doi.org/10.3390/ ijms22168460

\section{Academic Editors:}

Valentina Pallottini, Marco Segatto and Antimo Cutone

Received: 24 June 2021

Accepted: 19 July 2021

Published: 6 August 2021

Publisher's Note: MDPI stays neutral with regard to jurisdictional claims in published maps and institutional affiliations.

Copyright: (c) 2021 by the authors. Licensee MDPI, Basel, Switzerland. This article is an open access article distributed under the terms and conditions of the Creative Commons Attribution (CC BY) license (https:// creativecommons.org/licenses/by/ $4.0 /)$.
1 Immunometabolism Research Group, Department of Cell Biology and Development, Institute of Biomedical Science, University of Sao Paulo, Sao Paulo 05508-000, Brazil; loreana_loly@hotmail.com

2 LIM-26, Hospital das Clínicas of the University of São Paulo, Sao Paulo 01246-903, Brazil

3 Faculty of Medicine, School of Human Development and Health, University of Southampton, Southampton SO16 6YD, UK; p.c.calder@soton.ac.uk (P.C.C.); j.sethi@soton.ac.uk (J.K.S.)

4 National Institute for Health Research Southampton Biomedical Research Centre, University of Southampton and University Hospital Southampton National Health Service (NHS) Foundation Trust, Southampton SO16 6YD, UK

5 Institute for Life Sciences, University of Southampton, Southampton SO17 1BJ, UK

6 Interdisciplinary Post-Graduate Program in Health Sciences, Cruzeiro do Sul University, Sao Paulo 01506-000, Brazil; ruicuri59@gmail.com

7 Curtin Medical School and Curtin Health Innovation Research Institute, Curtin University, Perth, WA 6102, Australia; philip.newsholme@curtin.edu.au

* Correspondence: jrosaneto@usp.br

\begin{abstract}
Macrophages and lymphocytes demonstrate metabolic plasticity, which is dependent partly on their state of activation and partly on the availability of various energy yielding and biosynthetic substrates (fatty acids, glucose, and amino acids). These substrates are essential to fuelbased metabolic reprogramming that supports optimal immune function, including the inflammatory response. In this review, we will focus on metabolism in macrophages and lymphocytes and discuss the role of fatty acids in governing the phenotype, activation, and functional status of these important cells. We summarize the current understanding of the pathways of fatty acid metabolism and related mechanisms of action and also explore possible new perspectives in this exciting area of research.
\end{abstract}

Keywords: immune cells; lipids; fatty acids; metabolism; leukocytes; macrophages; lymphocytes; inflammation; cytokines

\section{Introduction}

Dietary fatty acids (FAs) are widely known to affect metabolic and cardiovascular health with different fatty acids having diverse effects [1]. In general, polyunsaturated fatty acids (PUFAs) are known to reduce the risk of cardiovascular disease [2] and to have therapeutic effects in both cardiovascular [3] and inflammatory diseases [4]. Beyond their effects on physiology, it is important to explore the molecular and cellular mechanisms of action of specific dietary FAs in order to better understand how they influence human health and wellbeing. The functioning of the immune system, for example, is well known to be intimately linked to FA and nutrient availability and energy status more generally $[5,6]$. The basis of this link can be found at the cellular level, where the combination of nutrient availability and metabolic status supports and often determines the spectrum of energydemanding activities that can be performed by distinct immune cell types, so enabling their functional capacity. Moreover, metabolic plasticity may be key to determining the ability of the immune system to adapt to a constantly changing microenvironment [7].

FAs have a hydrocarbon chain with a carboxyl group at one end and a methyl group at the other end of the chain [8]. The chain may vary in length and in degree of unsaturation (i.e., presence and number of double bonds). The naming of FAs relates to their structural 
features: they are described as short, medium, long, or very long depending upon chain length and saturated, monounsaturated, or polyunsaturated depending upon their degree of unsaturation [8]. There are two main classes of PUFAs called omega-3 and omega- 6 , also referred to as n-3 or n-6, respectively. The omega carbon is identified as the farthest from the carboxyl group [8]. The names, structures, and symbols of the fatty acids mentioned in this review are listed in Table 1.

Table 1. Names, chemical structures, and symbols of the fatty acids mentioned in this review.

\begin{tabular}{|c|c|c|c|}
\hline Common Name & IUPAC Name & Chemical Structure & Symbol \\
\hline Lauric acid & Dodecanoic acid & $\mathrm{CH}_{3}\left(\mathrm{CH}_{2}\right)_{10} \mathrm{COOH}$ & $12: 0$ \\
\hline Myristic acid & Tetradecanoic acid & $\mathrm{CH}_{3}\left(\mathrm{CH}_{2}\right)_{12} \mathrm{COOH}$ & 14:0 \\
\hline Palmitic acid & Hexadecanoic acid & $\mathrm{CH}_{3}\left(\mathrm{CH}_{2}\right)_{14} \mathrm{COOH}$ & $16: 0$ \\
\hline Stearic acid & Octadecanoic acid & $\mathrm{CH}_{3}\left(\mathrm{CH}_{2}\right)_{16} \mathrm{COOH}$ & 18:0 \\
\hline Palmitoleic acid & (Z)-hexadec-9-enoic acid & $\mathrm{CH}_{3}\left(\mathrm{CH}_{2}\right)_{5} \mathrm{CH}=\mathrm{CH}\left(\mathrm{CH}_{2}\right)_{7} \mathrm{COOH}$ & $16: 1 n-7$ \\
\hline Oleic acid & (Z)-octadec-9-enoic acid & $\mathrm{CH}_{3}\left(\mathrm{CH}_{2}\right)_{7} \mathrm{CH}=\mathrm{CH}\left(\mathrm{CH}_{2}\right)_{7} \mathrm{COOH}$ & $18: 1 n-9$ \\
\hline$\alpha$-Linolenic acid & $\begin{array}{l}\text { (9Z,12Z,15Z)-octadeca- } \\
\text { 9,12,15-trienoic acid }\end{array}$ & $\mathrm{CH}_{3} \mathrm{CH}_{2} \mathrm{CH}=\mathrm{CHCH}_{2} \mathrm{CH}=\mathrm{CHCH}_{2} \mathrm{CH}=\mathrm{CH}\left(\mathrm{CH}_{2}\right)_{7} \mathrm{COOH}$ & $18: 3 n-3$ \\
\hline Eicosapentaenoic acid & $\begin{array}{l}\text { (5Z,8Z,11Z,14Z,17Z)-icosa- } \\
5,8,11,14,17 \text {-pentaenoic acid }\end{array}$ & $\begin{array}{c}\mathrm{CH}_{3} \mathrm{CH}_{2} \mathrm{CH}=\mathrm{CHCH}_{2} \mathrm{CH}=\mathrm{CHCH}_{2} \\
\mathrm{CH}=\mathrm{CHCH}_{2} \mathrm{CH}=\mathrm{CHCH}{ }_{2} \mathrm{CH}=\mathrm{CH}\left(\mathrm{CH}_{2}\right)_{3} \mathrm{COOH}\end{array}$ & $20: 5 n-3$ \\
\hline Docosahexaenoic acid & $\begin{array}{l}\text { (4Z,7Z,10Z,13Z,16Z,19Z)-docosa- } \\
\text { 4,7,10,13,16,19-hexaenoic acid }\end{array}$ & $\begin{array}{c}\mathrm{CH}_{3} \mathrm{CH}_{2} \mathrm{CH}=\mathrm{CHCH}_{2} \mathrm{CH}=\mathrm{CHCH}_{2} \\
\mathrm{CH}=\mathrm{CHCH}_{2} \mathrm{CH}=\mathrm{CHCH}_{2} \mathrm{CH}=\mathrm{CHCH}_{2} \mathrm{CH}=\mathrm{CH}\left(\mathrm{CH}_{2}\right)_{2} \mathrm{COOH}\end{array}$ & $22: 6 n-3$ \\
\hline Linoleic acid & $\begin{array}{l}\text { (9Z,12Z)-octadeca-9,12- } \\
\text { dienoicacid }\end{array}$ & $\mathrm{CH}_{3}\left(\mathrm{CH}_{2}\right)_{4} \mathrm{CH}=\mathrm{CHCH}_{2} \mathrm{CH}=\mathrm{CH}\left(\mathrm{CH}_{2}\right)_{7} \mathrm{COOH}$ & $18: 2 n-6$ \\
\hline Arachidonic acid & $\begin{array}{l}\text { (5Z,8Z,11Z,14Z)-icosa- } \\
5,8,11,14 \text {-tetraenoic acid }\end{array}$ & $\begin{array}{c}\mathrm{CH}_{3}\left(\mathrm{CH}_{2}\right)_{4} \mathrm{CH}=\mathrm{CHCH}{ }_{2} \mathrm{CH}=\mathrm{CHCH}_{2} \mathrm{CH}=\mathrm{CH} \\
\mathrm{CH}_{2} \mathrm{CH}=\mathrm{CH}\left(\mathrm{CH}_{2}\right)_{3} \mathrm{COOH}\end{array}$ & $20: 4 n-6$ \\
\hline
\end{tabular}

IUPAC, International Union of Pure and Applied Chemistry.

Different subsets of immune cells appear to have differential metabolic profiles [9-11]. In other words, the metabolic signature of immune cells may vary according to their subtype, likely due to the necessity to generate adequate levels of energy in order to survive and for the production of intermediates in an attempt to maintain growth, proliferation, and function. Thus, there are likely to be alterations in the operation of different metabolic pathways-glycolysis, the citric acid (tricarboxylic acid (TCA) or Krebs) cycle, the pentose phosphate pathway (PPP), FA oxidation, FA synthesis, amino acid metabolism, and oxidative phosphorylation-to support the functional capacity of different immune cell subsets [12]. Macrophages are innate immune cells. As part of the first line of immune defense, the role of macrophages is to respond rapidly and appropriately to a variety of agents or physiological challenges. For this, they need to maintain a flexible functionality $[13,14]$. In general, they can be activated into pro-inflammatory macrophages (classically activated; formerly called M1) or anti-inflammatory macrophages (alternatively activated; formerly called M2) but there is a broad spectrum between these subtypes along with a broad range of activating stimuli [13-15]. The metabolic profiles of these macrophage subtypes are distinct. Pro-inflammatory macrophages generate ATP primarily from enhanced glycolysis, and biomaterials from enhanced PPP, glutaminolysis, inducible nitric oxide synthase-mediated arginine metabolism and lipogenesis [7]. Collectively this metabolic program supports the main microbicidal and tumoricidal roles of pro-inflammatory macrophages. Such macrophages can cause host tissue damage. In contrast, anti-inflammatory macrophages generate ATP primarily by enhanced oxidative phosphorylation and by $\beta$-oxidation of FAs, and biomaterials from proline and polyamine synthesis via arginase-dependent metabolism [16]. This program supports the roles of anti-inflammatory macrophages in wound repair, tissue remodeling, and tumor growth. There is evidence that FA oxidation induces the anti-inflammatory macrophage phenotype [11]. Although the necessity for FA oxidation to enable induction of anti-inflammatory polarization is still unclear [17], deletion 
of FA transporter proteins induces the pro-inflammatory phenotype in macrophages [18], indicating that FA utilization can reduce pro-inflammatory polarization.

$\mathrm{T}$ and $\mathrm{B}$ lymphocytes are part of adaptive immunity, while innate lymphoid cells and natural killer cells are part of the innate immune system. B cells produce antibodies while $\mathrm{T}$ cells have multiple roles in anti-bacterial, anti-viral, and anti-tumor defense according to specialized subsets [19]. There are several $\mathrm{T}$ cell subsets defined according to cell surface markers and cytokine profiles and functions [19]. In general, T cells are classified as CD4 ${ }^{+}$ ( $\mathrm{T}$ helper; Th) or $\mathrm{CD}^{+}$. $\mathrm{CD}^{+} \mathrm{T}$ cells may be further classified as naïve, Th1, Th2, $\mathrm{T}$ regulatory (Treg), Th17, or memory, while $\mathrm{CD}^{+} \mathrm{T}$ cells are further classified as naïve, cytotoxic, memory, or effector memory [19]. B lymphocytes are classified as naïve, memory, or plasma cells [19].

Immature T cells are found in the thymus and are initially CD4 and CD8 double negative. During their maturation they become both CD4 and CD8 double positive and then lose one or the other to produce naïve $\mathrm{CD} 4^{+}$or $\mathrm{CD} 8^{+} \mathrm{T}$ cells. Clonal expansion of $\mathrm{T}$ cells following rearrangement of the T cell receptor (TCR), which occurs as part of $\mathrm{T}$ cell maturation, requires energy and this is generated by glycolysis with glucose influx into the cells involving glucose transporter (GLUT)-1 [10]. Conversely, naïve T cells themselves revert to a low-energy state with a significant reduction in glucose transport [20].

Under resting conditions, $\mathrm{T}$ and $\mathrm{B}$ lymphocyte metabolism are distinct. Resting $\mathrm{T}$ lymphocytes have higher glucose uptake and ATP generation than resting B cells [21], which have higher mitochondrial mass and are more dependent on oxidative metabolism [22].

Regardless of the type of immune cell, both extracellular and intracellular FAs strongly influence their functionality. Extracellular FAs can be recognized and/or taken up by a range of cell membrane proteins including $G$ protein-coupled receptors, scavenger receptor CD36, fatty acid-binding proteins, or members of the fatty acid transport protein (FATP) family. Once inside the cell, FAs can be fuels for $\beta$-oxidation, substrates for complex lipid synthesis (e.g., phospholipids for cell membranes), substrates for lipid mediator synthesis, or signals for nuclear receptors that control expression of genes related to metabolism and inflammation amongst other processes [23,24].

Upon activation of Th1 lymphocytes, aerobic glycolysis predominates to sustain the rapid increase in demand for energy and biosynthetic intermediates [25]. In contrast, Th2 cells show high rates of FA oxidation [26]. Regulatory and memory T cells, which are not proliferative, also show a dependence on FA oxidation [7]. Finally, Th17 lymphocytes have a high capacity to produce ATP from glycolysis [27].

Thus, FA oxidation is important in some immune cell subsets and there seems to be a link between switching to FA oxidation and immune cell function [24]. We will now focus on FA metabolism in lymphocytes and macrophages and address the role of different FAs in the metabolism of these cells and the consequences of lipid overload. Finally, we will propose new horizons to clarify the role of FAs in immunometabolism.

\section{Fatty Acids and Macrophages}

\subsection{Fatty Acid Metabolism in Macrophage Subsets}

For an overview on macrophage metabolism, see Curi et al. [28]. As mentioned above, the most studied macrophage subsets are the classically activated (M1) phenotype and the alternatively activated (M2) phenotype. M1 macrophages are related to the Th1 lymphocyte response, type I inflammation, killing of intracellular pathogens and tumor resistance, while M2 macrophages are related to Th2 lymphocyte responses/activation, allergy, immune regulation, tissue remodeling, killing parasites, and tumor promotion [15]. M1 macrophages exhibit high glycolytic activity and the overexpression of GLUT-1 can induce classical activation of monocytes to the M1 subtype [29]. During M1 activation, the cytosolic accumulation of citrate allows for the production of specific lipid mediators by de novo lipogenesis [30]. By decreasing FA oxidation, M1 macrophages accumulate triacylglycerol and cholesterol-rich lipid droplets [31,32]. Thus, M1 macrophages have lower FA uptake and oxidation than M2 macrophages but raised de novo lipogenesis [33]. 
Activating pro-inflammatory cytokines have been reported to decrease the level of FATP, thereby decreasing FA uptake [18]; this provides a link between pro-inflammatory stimuli and macrophage metabolism. Figure 1 describes some key metabolic differences between M1 and M2 macrophages.

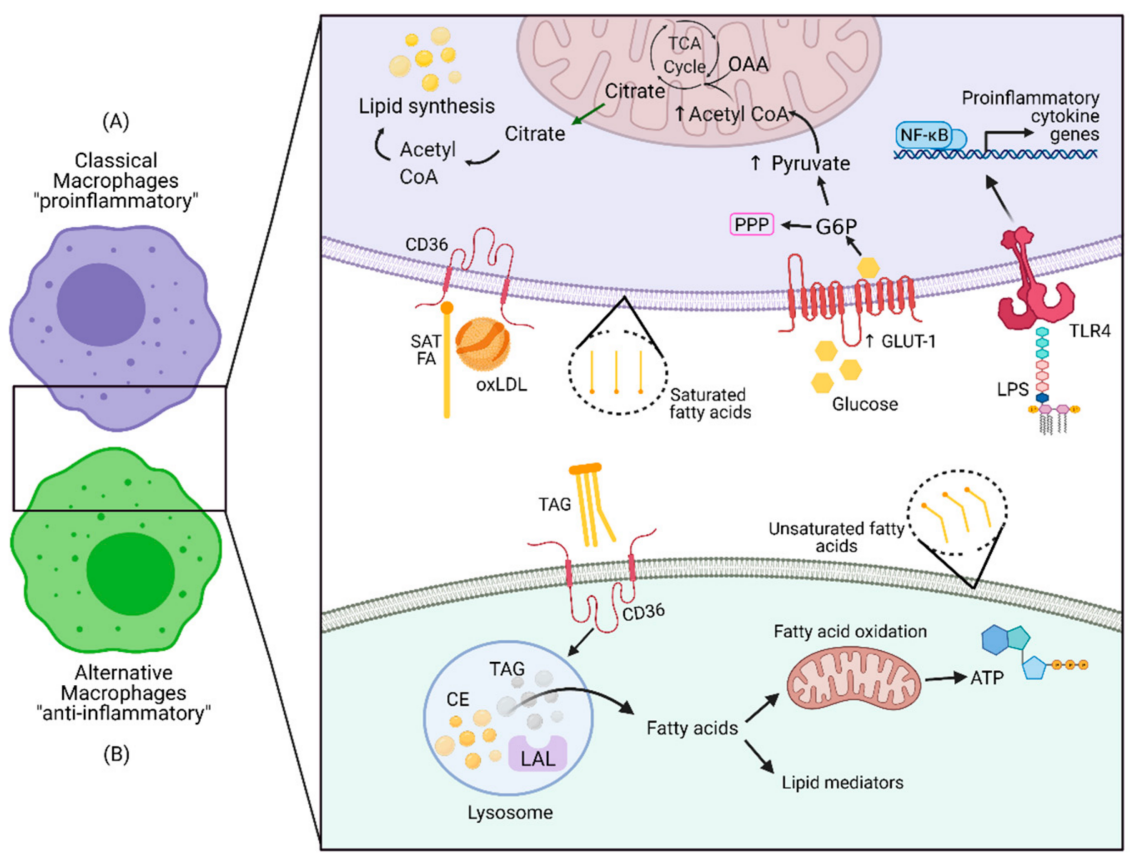

Figure 1. Overview of macrophage metabolism. (A) Classically activated macrophages (proinflammatory macrophages [M1]) present a more glycolytic metabolism, even in the presence of oxygen. Their increased GLUT-1 transporter enables higher glucose influx and enhances pentose phosphate pathway (PPP) activity, which is essential for the inflammatory phenotype. The incomplete TCA cycle generates excess citrate, which is crucial for de novo lipid synthesis. The membrane of M1 macrophages has a high content of saturated fatty acids, especially palmitic acid. LPS binding to TLR4 activates nuclear factor kappa B (NF- $\mathrm{KB})$, responsible for transcription of proinflammatory cytokine genes. (B) Metabolism in alternatively activated macrophages (anti-inflammatory macrophages [M2]) mainly produces ATP via the TCA cycle and oxidative phosphorylation (OXPHOS) fueled by fatty acid $\beta$-oxidation. There is low glycolysis and PPP activity in this subtype of macrophage. Abbreviations: CD: cluster of differentiation; LAL: lysosomal acid lipase; OAA: oxaloacetate; TCA: tricarboxylic acid cycle; G6P: glucose-6-phosphate; TLR-4: Toll-like receptor 4; SAT: saturated fatty acids; FA: fatty acid; oxLDL: oxidized low-density lipoprotein; GLUT-1, glucose transporter 1; TAG: triacylglycerol; LPS: lipopolysaccharide; CE: cholesteryl ester; ATP: adenosine triphosphate. Created with biorender.com.

FA oxidation is necessary to support the functions of alternatively activated macrophages [34]. FATP-1 deletion, specifically in myeloid cells, reduces FA oxidation and increases glycolytic flux in macrophages [18]. Mice fed a high-fat diet exhibit impaired whole-body glucose metabolism and higher inflammation in adipose tissue with the deletion of FATP-1 in myeloid cells [18]. Overexpression of FATP-1 in RAW267 macrophages reduces M1 polarization by modulating lipid mediators: macrophages with FATP-1 overexpression had lower arachidonic acid synthesis and increased levels of arachidonic acid metabolites 15-hydroxyeicosatetraenoic acid (HETE) and 12-HETE [18].

In mammalian cells, one important lipogenic transcription factor is peroxisome proliferator activated receptor (PPAR) $\gamma$ [35]. Several lipids such as docosahexaenoic acid (DHA), eicosapentaenoic acid (EPA), and palmitic acid can activate this transcription factor [36-38]. $\mathrm{Xu}$ et al. reported that 12- and 15-HETE induce PPAR $\gamma$ activation [35]. PPAR $\gamma$ promotes anti-inflammatory actions and is crucial for the differentiation to alternatively activated 
macrophages [39]. Consistent with this, the deletion of PPAR $\gamma$ in myeloid cells has been shown to reduce the expression of CD206, a surface marker of M2 macrophages [40]. However, in the same study of obese mice, the anti-inflammatory response caused by aerobic training was maintained in adipose tissue by restoring adipocyte area and reducing tumor necrosis factor (TNF)- $\alpha$ and interleukin (IL)- $1 \beta$ secretion [40]. Moreover, mice with the same deletion of PPAR $\gamma$ in myeloid cells demonstrated impaired muscle regeneration as a result of a defective remodeling phase after injury [41]. Thus, PPAR $\gamma$ expression in myeloid cells is required to activate the phenotype of macrophages necessary for skeletal muscle repair after injury [41].

\subsection{Fatty Acid Overload in Macrophages}

The availability of specific types of FAs can lead to altered cell membrane composition and biophysical properties. The treatment of human macrophages with saturated FAs modified the phospholipid FA composition and induced an increase in the saturated/unsaturated ratio in cell phospholipids [42]. The high content of saturated FAs, especially stearic acid, in phospholipids reduced the membrane fluidity and promoted the impairment of $\mathrm{Na}^{+} / \mathrm{K}^{+}$-ATPase, leading to the elevation of intracellular $\mathrm{K}^{+}$levels [42]. This effect was counteracted by co-treatment with the monounsaturated FA oleic acid [42]. Poledne et al. [43] related adipocyte phospholipid FAs to macrophage subtypes present in human adipose tissue. They found that palmitic and palmitoleic acids in adipocyte phospholipids were positively associated with M1 macrophages while stearic acid, $\alpha$-linolenic acid, EPA, total n-3 FAs, and the ratio of n-3 to n- 6 FAs were inversely associated. Conversely, stearic acid, $\alpha$-linolenic acid, EPA, total n-3 FAs, and the ratio of n-3 to n- 6 FAs were positively associated with M2 macrophages and palmitoleic acid was inversely associated. The positive relationship between palmitic acid and M1 macrophages fits with earlier data showing that saturated FAs, including palmitic acid, enhance inflammation [44-47]. Palmitic acid may stimulate macrophages directly via Toll-like receptor (TLR)-4 [37,44]. However, palmitic acid also reduces mitochondrial adenine nucleotide translocator activity, increasing intracellular ATP content and reducing adenosine $5^{\prime}$ monophosphate-activated protein kinase (AMPK) activity [37]. The positive relationship of omega-3 FAs with M2 macrophages fits with the generally accepted anti-inflammatory effects of these fatty acids $[48,49]$. However, their relationships with palmitoleic acid are unclear, since this FA exhibits an anti-inflammatory effect in vitro [50,51], which seems to involve AMPK activation [50]. On the other hand, palmitoleic acid promotes the differentiation of macrophages into the M2 phenotype independent of the lipid sensor PPAR $\gamma$ [52]. In this sense, the balance between FA oxidation and FA synthesis may be essential to macrophage polarization and function. There is increased FA production by acyl-CoA synthetase-1 (ACS-1) in macrophages stimulated with lipopolysaccharide (LPS) and knockdown of ACS-1 reduces the inflammatory response after LPS treatment [53].

Oxidized low-density lipoproteins that are taken up by CD36 promote mitochondrial reprogramming in macrophages characterized by lower FA oxidation and enhanced aerobic glycolysis [54]. The mechanism by which the oxidized low-density lipoproteins induce this reprogramming is still unclear, but macrophage exposure to oxidized phospholipids in oxidized low-density lipoproteins increases aerobic glycolysis [54].

In humans, macrophages derived from monocytes showed an association between membrane lipid composition and polarization state with specific phospholipid remodeling within the M2a and M2c subsets [55]. A question that arises in the context of FAs orchestrating immune cell phenotypes is whether circulating cells in people with obesity are affected by the enhanced exposure to lipids in plasma. Ghanim et al. studied mononuclear cells from healthy non-diabetic individuals with obesity. They concluded that these cells contribute to elevated pro-inflammatory cytokine concentrations, including TNF$\alpha$ and IL-6, via enhanced nuclear factor kappa-light-chain-enhancer of activated B cells (NFKB) transcriptional activity [56]. One aspect of the anti-inflammatory actions of omega3 FAs could be attenuation of macrophage differentiation towards more inflammatory 
phenotypes. The treatment of obese people with $\alpha$-linolenic acid ( $4 \mathrm{~g} /$ daily for 12 weeks) decreased plasma free FAs and pro-inflammatory cytokines and increased PPAR $\gamma$ mRNA expression in mononuclear cells [57]. Adolescents with obesity who received $1.2 \mathrm{~g} /$ day of omega-3 FAs for the same period of intervention had elevated serum omega-3 FA concentrations together with lower inflammatory markers [58]. Apart from the control of macrophage metabolism and function by FAs, Lau et al. [59] reported that monocytederived macrophages from patients with Alzheimer's disease treated with omega-3 FAs had increased ATP synthesis through oxidative phosphorylation [59], suggesting a move to a less inflammatory phenotype.

\subsection{Fatty Acid-Stimulated Regulation of Macrophage Function}

The link between high fat diet-induced obesity and chronic low-grade inflammation involves an increased pro-inflammatory state, including M1 macrophage polarization [60]. We review here the effects of different FAs on three principal macrophage functions: chemokine production, phagocytosis and adhesion.

Treatment of adipocytes with saturated FAs (lauric, myristic, and palmitic acids) increased the expression of the chemokine CCL2 (monocyte chemoattractant protein 1 (MCP-1)) [61], which induces the chemoattraction of non-resident monocytes. Co-treatment with the omega-3 FA DHA reversed the effect of saturated FAs in a PPAR $\gamma$-dependent manner [61]. Similarly, treatment of macrophages with palmitic acid stimulated MCP-1 and IL-8 expression [62]. Palmitic acid treatment increased macrophage production of IL-8 and CXCL1 [63]. Conversely, macrophages treated with palmitoleic acid exhibited reduced LPS-induced MCP-1 expression [51]. Co-treatment with oleic acid and LPS did not blunt MCP-1 protein expression in macrophages [64]. The omega-3 FAs EPA and DHA $(100 \mu \mathrm{M})$ reduced MCP-1 production by LPS-stimulated monocytes [65] and MCP-1 and IL-8 production by TNF-stimulated endothelial cells $(25 \mu \mathrm{M}$ or $50 \mu \mathrm{M})$ [66]. DHA also decreased regulated, normal T cell expression and presumably secreted (RANTES) production by TNF-stimulated endothelial cells upon activation [66]. Specific FAs have been shown to modulate macrophage phagocytosis. For example, PUFAs enhanced phagocytosis $[67,68]$, while saturated FAs impair phagocytosis, an effect related to the fatty acid composition of the cell membrane [69]. The effects of FAs, particularly omega-3 FAs, on adhesion molecules and leukocyte-endothelial adhesion were reviewed recently [70]. Both EPA and DHA can decrease the expression of key adhesion molecules, such as vascular cell adhesion molecule 1, and result in reduced adhesive interactions between leukocytes and endothelial cells.

\subsection{Fatty Acids as Signaling Molecules in Macrophages}

Saturated FAs are co-regulators of LPS/TLR-4 activation, and co-treatment with palmitic acid and LPS induces a substantial inflammatory response [71]. However, the reason for saturated FAs co-stimulating signaling via LPS/TLR-4 is unclear. Rowe et al. reported that the myristoylation of TIR-domain-containing adapter-inducing interferon$\beta$ (TRIF)-related adaptor molecule is an essential step in signal transduction within the LPS/TLR-4 pathway [72]. Furthermore, the conjugation of palmitic acid with cysteine 113 and 274 residues of myeloid differentiation primary response 88 (MYD88) is necessary to activate the LPS/TLR-4 downstream activities [73]. The activation of CD36 and fatty acid synthase are essential to this palmitoylation of MYD88 [73]. This may be why palmitic acid co-stimulates the LPS/TLR-4 system. The anti-inflammatory effects of palmitoleic acid may be due to a reduction in CD36 expression and subsequent decline in FA uptake [52]. Molecular docking experiments showed that palmitoleic acid has a high affinity with the F126 loop site of MD2, a TLR-4 adaptor essential for canonical activation of the TLR-4 pathway. The binding between palmitoleic acid and the F126 loop modifies the structure of MD-2 protein and reduces the docking between TLR-4/MD2 [52].

Another relevant mechanism is the role of FAs in membrane lipid raft formation underpinning pro-inflammatory and anti-inflammatory pathways. TLR-4 stabilization 
by lipid rafts rich in cholesterol is considered important in the activation of LPS/TLR4 [74]. Saturated FAs were demonstrated to promote raft formation in LPS-stimulated cells $[44,46]$, an effect that was prevented by the omega-3 FA DHA. LPS/TLR-4 affects cell membrane lipid composition and fluidity, probably by a fatty acid synthase-dependent mechanism [74,75]. The concept of modification in membrane fluidity and macrophage function has been under debate for a long time. Calder et al. discussed the role of PUFAs in enhanced macrophage phagocytosis associated with this concept [69]. Omega-3 and omega6 PUFAs appear to have differential incorporation into membrane lipids and therefore differentially affect lipid raft formation, altering inflammatory responses [76]. However, there are still gaps in our understanding of the mechanisms of incorporation of FAs and their effects on lipid rafts and inflammatory signaling in macrophages.

Different lipid classes have a crucial role in the inflammatory response and the role of FA-mediated signaling induced by different lipid mediators, like prostaglandins, leukotrienes, maresins, and resolvins, is gaining increased attention. Metabolomics and lipidomics now allow the investigation of the involvement of many other lipid classes in macrophage inflammatory responses [77]. It is known that sphingolipids, ceramides, phospholipids, lyso-phospholipids, and endocannabinoids can modify macrophage responses. For example, the formation of ceramides from neutral sphingomyelinase-2 is a crucial step in the TNF- $\alpha$ response of macrophages [78]. The role of different FAs in the formation, degradation, and activity of these different endogenous lipids in the context of macrophage function is an exciting avenue to investigate.

Thus, classical and alternative macrophages show differences in FA metabolism. This difference is important for supplying the correct metabolic intermediaries to different stages of activation of macrophages, supporting their functions. Moreover, the different lipid classes and the individual FAs themselves can modulate the immune response. Therefore, both FA metabolism and the type of FAs available to cells can be relevant to induction or inhibition of the immuno-inflammatory response.

\section{Fatty Acids and Lymphocytes}

\subsection{Summary of Fatty Acid Metabolism in Lymphocytes}

Lymphocytes utilize glucose and glutamine at high rates [79]. Burns et al. [80] reported that palmitic acid oxidation was higher in lymphocytes than neutrophils. The membrane FA composition and fluidity and the activation of membrane proteins vary according to the activation state of lymphocytes [81,82].

\subsection{CD4 T Lymphocytes and Fatty Acid Metabolism}

Different subsets of $\mathrm{CD} 4^{+} \mathrm{T}$ cells have different metabolic signatures. $\mathrm{T}$ cell activation occurs by TCR recognition of ligands presented by major histocompatibility complex after exposure to an antigen-presenting cell and is associated with co-stimulatory signaling by CD28. As previously mentioned, this step of $\mathrm{T}$ cell activation requires aerobic glycolysis for rapid ATP production together with the Warburg effect necessary for nucleotide generation, lipid synthesis, and biomass induction [83]. The primary regulators for these mechanisms are the mechanistic target of rapamycin (mTOR) induced downstream via phosphoinositide 3-kinase-protein kinase B (PI3K-AKT) signaling and c-Myc [84].

After the activation of T lymphocytes, the flux of carbon generated by the TCA cycle is redirected to lipid synthesis: excess citrate produced in the TCA cycle is transported from the mitochondria to the cytosol, where it is converted to acetyl-CoA, elongated to malonylCoA by acetyl CoA carboxylase (ACC), and consequently used for FA, cholesterol, and triglyceride biosynthesis [83]. ACC is an essential enzyme for T cell expansion [85]. In vitro studies have shown that FA uptake increases during T cell proliferation [86]. During the activation of $\mathrm{T}$ effector cells, mitochondrial fission reduces electron transport chain efficiency, a mechanism regulated by dynamin related protein- 1 and necessary to induce the Warburg effect, decreasing the rate of FA oxidation [87]. 
During CD4 cell activation, there is an increase in the content of palmitic acid in three lipids classes: diacylglycerol, phosphatidylethanolamine, and hexosylceramides [88]. Arachidonic, palmitic, palmitoleic, and myristic acids were all higher in triacylglycerols after stimulation of CD4 $\mathrm{T}$ cells [88].

Regarding CD4 T cell subsets, Th1, Th2, and Th17 lymphocytes have the greatest ATP production from glycolysis, with a considerable increase in GLUT-1 expression sustained by mTOR complex (mTORC) 1 activation [25]. In contrast, ATP production in Treg cells mainly occurs through FA oxidation $[24,25]$ where the high AMPK activity regulates FA oxidation [24]. Furthermore, in Tregs the mTORC pathway is inhibited by phosphatase and tensin homolog (PTEN) [89]; PTEN is a phosphatase that is able to dephosphorylate phosphoinositol 3-phosphate, which is essential to activation of the AKT/mTORC pathway [89]. Memory T lymphocytes primarily use FA oxidation for ATP production [7].

The differentiation from CD4 T naïve cells to CD4 Th17 cells and the activation of Th17 cells are both dependent on FA synthesis [90]. Berod et al. showed that the inhibition of ACC reduces Th17 differentiation and induces Treg differentiation [91]. Glycolyis is a key step involved in the induction of Th17 cells, an increase in long chain acylcarnitine, and a reduction in $\beta$-oxidation occuring together with Th17 differentiation and activation [92].

Hradilkova et al. reported that re-stimulated Th1 lymphocytes presented increased FA oxidation and reduced glycolysis [93]. This metabolic feature associates with Twist-1 expression that promotes FA oxidation and protects the lymphocytes against oxidative stress [93].

Interestingly, follicular helper $\mathrm{T}$ cells, which are essential for the activation of $\mathrm{B}$ lymphocytes and humoral immunity, require the activation of phosphoethanolamine synthesis as a key step for differentiation [94].

\subsection{CD8 T Lymphocytes and Fatty Acid Metabolism}

Activation of $\mathrm{CD}^{+} \mathrm{T}$ cells induces metabolic reprogramming mainly towards increased aerobic glycolysis [25] for which CD28 co-stimulation is necessary [95]. Thus, the intermediates of the TCA cycle are used in biosynthetic pathways. Regarding FA metabolism, de novo lipogenesis is essential to sustaining CD8 effector T cell activity [96]. In general, FA oxidation is unnecessary to this subset [97]. Nonetheless, programmed cell death protein 1 (PD-1) signaling can switch the metabolic signature of these cells to FA oxidation [98]. Moreover, $\mathrm{CD}^{+}$effector cells show mitochondrial fission, and inhibition of proteins that regulate this fission leads to the differentiation of CD8 cells to memory cells [87].

CD8 memory T cells have reduced mTORC1 activity and use FA oxidation as the primary ATP source [97]. Thus, mitochondrial biogenesis is necessary to meet the energy demands of CD8 memory cells $[87,99]$. Nevertheless, Sukumar et al. described that the induction of glycolysis during the differentiation of CD8 memory cells leads to short-term CD8 memory [100]. On the other hand, the inhibition of glycolysis during memory T cell development induces a robust long-term CD8 memory phenotype [100]. The metabolic reprogramming of the CD8 memory subset is induced by IL-15, which induces the mitochondrial transcription factor A to promote mitochondrial biogenesis [101]. The primary site of lipolysis in the CD8 memory subset is lysosomes [102]. Moreover, CD8 memory cells, mainly the central memory T lymphocytes found in lymph nodes, can store triglycerides, while the source of FAs for oxidation in skin CD8 memory T cells is extracellular $[97,103]$. Finally, a higher mitochondrial mass is a metabolic advantage when CD8 memory cells are re-stimulated because of the increased ATP demand which is met by a rapid increase in glycolysis and higher oxidative metabolism [104].

\subsection{B Lymphocytes and Fatty Acid Metabolism}

B lymphocytes play a role in the humoral response, producing antibodies and a memory response. After $\mathrm{B}$ cell receptor (BCR) engagement, together with co-stimulatory signals, B cells undergo rapid clonal expansion. Like T cells, this step depends on glycolysis 
and regulation by the PI3K-AKT-mTORC1 axis [9]. Glutamine uptake and metabolism increase after BCR activation, as does lipid biosynthesis. However, unlike in T cells, there is higher coordination between oxidation of glucose and FAs and glycolysis [9].

In plasma cells, which are crucial for antibody production, glycolysis and oxidative glucose metabolism are activated in order to support increased mitochondrial capacity associated with the biosynthesis of antibodies $[105,106]$. In addition to their high mitochondrial mass, plasma cells exhibit increased autophagy: AMPK, a regulator of autophagy, is essential to generate long-term memory B cells $[107,108]$.

The microanatomical structures found in follicles of germinal centers control B lymphocyte metabolism and long-term immunity [109]. In germinal centers, B cells are formed and memory B cells and long-lived plasma cells are maintained [110]. As observed for T lymphocytes, the glycolytic response is predominant in the proliferation phase of B cells in germinal centers [111]. However, Weisel et al. recently reported that FA oxidation in mitochondria and peroxisomes is the key metabolic pathway during the development and survival of B cells in germinal centers [112].

In summary, resting B cells have a lower production rate of ATP than T lymphocytes [21]. After activation, there is an increase in glycolytic flux, and the requirement for glucose and FA oxidation is higher than for T cells. During activation and antibody production, plasma cells increase flux through glycolysis, but long-term memory B lymphocytes are dependent on mitochondrial mass, autophagy, and FA oxidation. The metabolism of $B$ cells in germinal centers is still unclear, but recently a high need for FA oxidation has been documented [112]. The current understanding of B lymphocyte metabolism is less complete than the knowledge of T lymphocyte metabolism. Some key metabolic pathways in activated B and T cells are described in Figure 2.

\subsection{Fatty Acid-Stimulated Regulation and Overload in Lymphocytes}

The type of FA in the extracellular environment and taken up can result in different functional effects in lymphocytes. EPA and DHA can reduce $\mathrm{CD} 4^{+} \mathrm{T}$ cell activation and chemokinesis in allograft immunization mice [113]. Besides this, in vitro treatment of $\mathrm{CD}^{+} \mathrm{T}$ lymphocytes with omega-3 FAs modified the membrane microdomains to reduce activation [113]. $\mathrm{CD} 4^{+} \mathrm{T}$ cells treated with EPA and DHA demonstrated a reduction in activity after antigen presentation [114].

The treatment of antigen presenting cells with palmitic acid impairs antigen presentation to CD8 lymphocytes [115], an effect which is mitigated by co-treatment with oleic acid [115]. Lymphocytes treated with palmitoleic acid had reduced proliferation, CD28 surface expression, and pro-inflammatory cytokine production (interferon- $\gamma$, IL-17, IL-6 and TNF- $\alpha$ ), whereas IL-4, IL-10, and IL-2 production increased [116]. The palmitoleic acid/palmitic acid ratio positively correlated with PD-1 expression on the surface of CD4 ${ }^{+}$ cells [116]. Non-alcoholic fatty liver disease progression is associated with a low palmitoleic acid/palmitic acid ratio and low expression of PD-1 on CD4 $4^{+}$lymphocytes [117]. Interestingly PD-1 activation in T lymphocytes induces metabolic reprogramming with enhancement of FA oxidation and is associated with exhausted lymphocytes [98].

The interaction between microbiota-derived short-chain fatty acids and lymphocytes has been investigated mainly in the context of inflammatory bowel diseases. The production of acetate is essential to the effectiveness of memory CD8 cells [118]. Of note, acetate can sustain acetyl-CoA formation in glucose-restricted conditions and maintain the effector function of $\mathrm{CD}^{+}$cells [119]. Short-chain fatty acids can induce IL-22 production by CD4 ${ }^{+}$ T cells [120]; IL-22 is essential to mucosal immunity and the gut epithelial barrier.

In mice, lipid-rich diets elevated chemokine expression by lymphatic endothelial cells promoting T lymphocyte movement to lymph nodes [121]. This effect may be mediated by palmitic acid as suggested in a study with a co-culture system of lymphocytes and lymphatic endothelial cells [121]. 

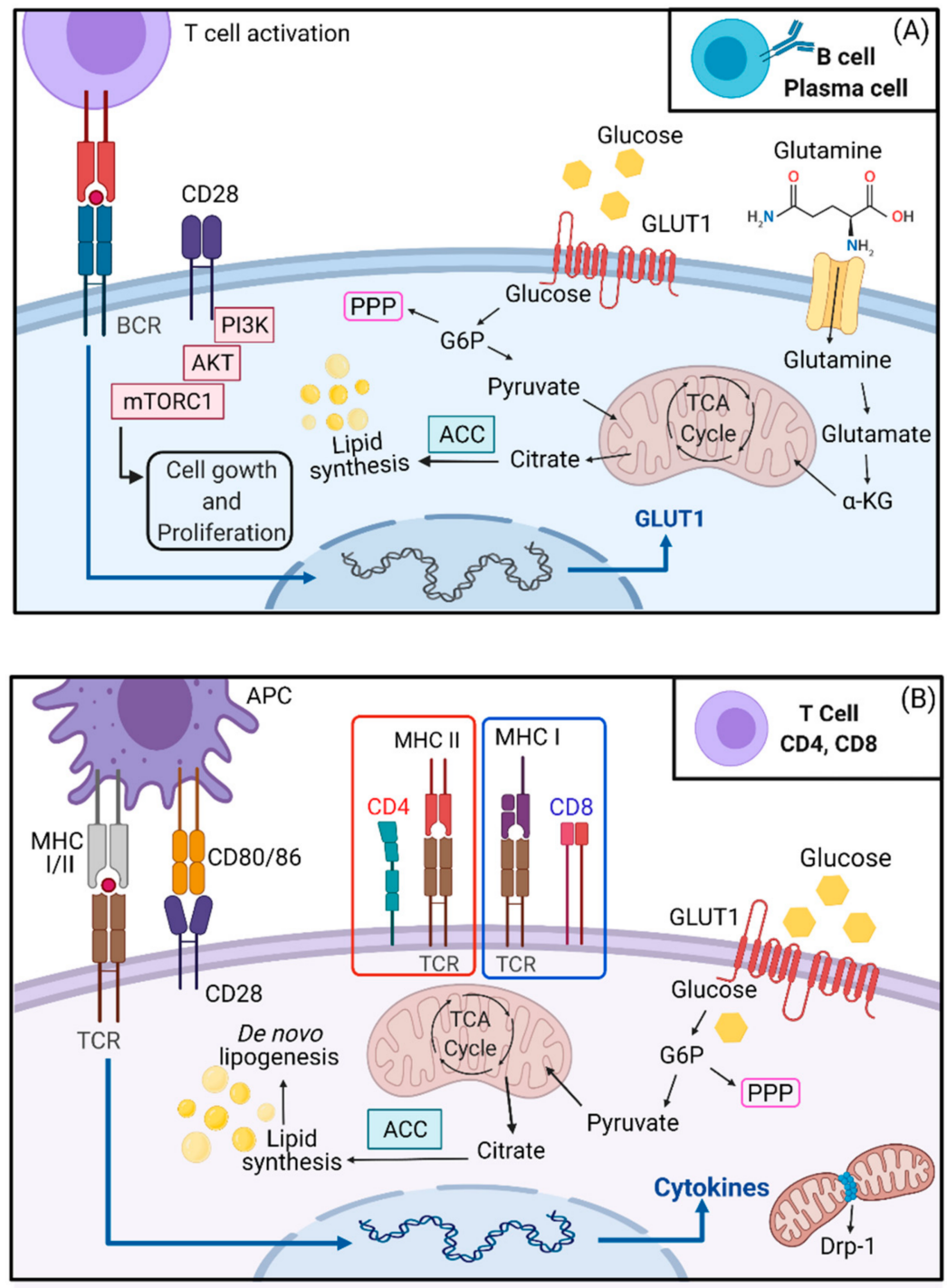

Figure 2. B and T cell activation and metabolism. (A) B cells (plasma cells) are activated by a T cell via BCR. Transcription of GLUT-1 is increased and favors glucose uptake and aerobic glycolysis. The pentose phosphate pathway (PPP) is required for redox balance and nucleotide synthesis whereas pyruvate and $\alpha K G$ go to the TCA cycle. Citrate excess is redirected to lipid synthesis. CD28 activation is required for long-lived plasma cells by stimulating growth and proliferation. (B) T cell activation occurs via APCs, in which MHC I or II binds to TCR and the co-stimulatory CD28. Drp-1 regulates mitochondrial fission playing an important role in metabolic reprogramming, proliferation, and migration in activated T cells. Glycolysis is upregulated and most of the pyruvate is excreted from the cell as lactate. Citrate from the TCA cycle is used for lipid synthesis. The PPP is important for generating NADPH and nucleotide synthesis. Abbreviations: CD: cluster of differentiation; TCA: tricarboxylic acid cycle; G6P: glucose-6-phosphate; GLUT-1: glucose transporter; Drp-1: dynamin related protein-1; TCR: T cell receptor; MHC: major histocompatibility complex; APC: antigen presenting cell; ACC: acetyl-CoA carboxylase. Created with biorender.com.

People with so-called healthy morbid obesity have alterations in peripheral $\mathrm{T}$ cell subsets with higher $\mathrm{CD}^{+}$cells than their normal-weight comparators [122]. This enhanced $\mathrm{CD}^{+}$population in people with obesity is composed mainly of $\mathrm{T}$ naïve, $\mathrm{T}$ central memory, and Th2 cells [123]. However, the mechanisms that may explain this contrast found in $\mathrm{T}$ cells from people with obesity (higher $\mathrm{CD} 8^{+}$cells in adipose tissue and higher $\mathrm{CD} 4^{+}$cells in peripheral blood) are still unclear. In a pilot study, the B cell response in people with obesity was affected by 12 weeks of supplementation with fish oil, a source of EPA and 
DHA, resulting in lower percentages of memory and plasma cells, supporting the idea that these FAs interfere with T cell activation [124]. Thus, the type of FA and lipid overload both regulate the function of lymphocytes [125]. However, more studies are necessary to determine further details of the effects of different FAs on $\mathrm{T}$ and B lymphocyte function.

In summary, the metabolism of FAs is essential to T and B cell polarization and function. Increased de novo lipogenesis is associated with a pro-inflammatory phenotype and with Th1, Th17, and plasma cells. On the other hand, FA oxidation induces tolerogenic and memory responses with increased Treg and $\mathrm{T}$ and $\mathrm{B}$ memory cells. Moreover, the type of FA present is able to influence the profile of lipid mediators and can modify the immune response. Monounsaturated fatty acids and n-3 PUFAs promote regulatory and suppressive functions in T and B lymphocytes while saturated and n-6 PUFAs promote the inflammatory pathway. Thus, the control of FA metabolism is essential to fine-tune lymphocyte function.

\section{Concluding Remarks}

In summary, a complex link between FA metabolism and the role of different FAs in regulating lymphocyte and macrophage functions has been revealed but requires further investigation. Briefly, FA oxidation is essential to the alternative/regulatory phenotype of macrophages and lymphocytes. On the other hand, de novo lipogenesis and FA synthesis are associated with rapid clonal expansion and a pro-inflammatory phenotype in macrophages and lymphocytes. Thus, the different pathways of FA metabolism are keys to immune cell differentiation and function, but key regulatory steps remain to be identified. With further clarification, new understandings of how cell-specific immunometabolic programs support exact biological responses against pathogens and tumors, and in immuneaging and autoimmune diseases, could be revealed. This could facilitate the development of new therapeutic approaches, by action directly on metabolic pathways or by immunonutrition with intake of FAs to promote a more optimal immune response (e.g., increase in omega-3 FAs to reduce chronic inflammation). The delivery of specific FAs to specific immune cells may be a limitation in developing such targeted therapies. However, using gene editing it may be possible that the silencing or hyperexpression of metabolic pathways of immune cells can be used to improve immune responses.

Author Contributions: J.C.R.N. and L.S.S. conceived of the article; L.S.S. drafted the article; all authors reviewed the draft and had substantial input; all authors agreed the final content. All authors have read and agreed to the published version of the manuscript.

Funding: This research received no funding. The APC was funded by Fundação à Pesquisa do Estado de São Paulo (FAPESP) (Grant numbers FAPESP: 2019/09679-2 and FAPESP: 2019/09854-9).

Institutional Review Board Statement: Not applicable.

Informed Consent Statement: Not applicable.

Data Availability Statement: Not applicable.

Acknowledgments: J.C.R.N. is funded by Fundação à Pesquisa do Estado de São Paulo. Figures were created with Biorender.

Conflicts of Interest: The authors declare no conflict of interest.

\section{References}

1. Calder, P.C. Functional roles of fatty acids and their effects on human health. JPEN J. Parenter. Enter. Nutr. 2015, 39, 18S-32S. [CrossRef] [PubMed]

2. Elagizi, A.; Lavie, C.J.; O’Keefe, E.; Marshall, K.; O’Keefe, J.H.; Milani, R.V. An update on omega-3 polyunsaturated fatty acids and cardiovascular health. Nutrients 2021, 13, 204. [CrossRef] [PubMed]

3. Sokoła-Wysoczańska, E.; Wysoczański, T.; Wagner, J.; Czyż, K.; Bodkowski, R.; Lochyński, S.; Patkowska-Sokoła, B. Polyunsaturated fatty acids and their potential therapeutic role in cardiovascular system disorders-a review. Nutrients 2018, $10,1561$. [CrossRef] 
4. $\quad$ Margină, D.; Ungurianu, A.; Purdel, C.; Nițulescu, G.M.; Tsoukalas, D.; Sarandi, E.; Thanasoula, M.; Burykina, T.I.; Tekos, F.; Buha, A.; et al. Analysis of the intricate effects of polyunsaturated fatty acids and polyphenols on inflammatory pathways in health and disease. Food Chem. Toxicol. 2020, 143, 111558. [CrossRef] [PubMed]

5. Calder, P.C. Fuel utilization by cells of the immune system. Proc. Nutr. Soc. 1995, 54, 65-82. [CrossRef] [PubMed]

6. Calder, P.C. Feeding the immune system. Proc. Nutr. Soc. 2013, 72, 299-309. [CrossRef]

7. Zhang, X.; Zink, F.; Hezel, F.; Vogt, J.; Wachter, U.; Wepler, M.; Loconte, M.; Kranz, C.; Hellmann, A.; Mizaikoff, B.; et al. Metabolic substrate utilization in stress-induced immune cells. Intensive Care Med. Exp. 2020, 8. [CrossRef] [PubMed]

8. Petrovic, S.; Arsic, A. Fatty Acids: Fatty Acids. In Encyclopedia of Food and Health; Caballero, B., Finglas, P.M., Toldrá, F., Eds.; Academic Press: Oxford, UK, 2016; pp. 623-631.

9. Boothby, M.; Rickert, R.C. Metabolic regulation of the immune humoral response. Immunity 2017, 46, 743-755. [CrossRef]

10. MacIver, N.J.; Michalek, R.D.; Rathmell, J.C. Metabolic regulation of T lymphocytes. Annu. Rev. Immunol. 2013, 31, 259-283. [CrossRef] [PubMed]

11. Van den Bossche, J.; Saraber, D.L. Metabolic regulation of macrophages in tissues. Cell. Immunol. 2018, 330, 54-59. [CrossRef] [PubMed]

12. O'Neill, L.A.J.; Kishton, R.J.; Rathmell, J. A guide to immunometabolism for immunologists. Nat. Rev. Immunol. 2016, 16, 553-565. [CrossRef]

13. Williams, J.W.; Giannarelli, C.; Rahman, A.; Randolph, G.J.; Kovacic, J.C. Macrophage biology, classification, and phenotype in cardiovascular disease: JACC Macrophage in CVD Series (Part 1). J. Am. Coll. Cardiol. 2018, 72, 2166-2180. [CrossRef] [PubMed]

14. Liu, X.; Zhang, J.; Zeigler, A.C.; Nelson, A.R.; Lindsey, M.L.; Saucerman, J.J. Network analysis reveals a distinct axis of macrophage activation in response to conflicting inflammatory cues. J. Immunol. 2021, 206, 883-891. [CrossRef]

15. Martinez, F.O.; Gordon, S. The M1 and M2 paradigm of macrophage activation: Time for reassessment. F1000Prime Rep. 2014, 6, 13. [CrossRef] [PubMed]

16. Silveira, L.S.; Antunes Bde, M.; Minari, A.L.; Dos Santos, R.V.; Neto, J.C.; Lira, F.S. Macrophage polarization: Implications on metabolic diseases and the role of exercise. Crit. Rev. Eukaryot. Gene Expr. 2016, 26, 115-132. [CrossRef]

17. Van den Bossche, J.; O’Neill, L.A.; Menon, D. Macrophage immunometabolism: Where are we (going)? Trends Immunol. 2017, 38, 395-406. [CrossRef] [PubMed]

18. Johnson, A.R.; Qin, Y.; Cozzo, A.J.; Freemerman, A.J.; Huang, M.J.; Zhao, L.; Sampey, B.P.; Milner, J.J.; Beck, M.A.; Damania, B.; et al. Metabolic reprogramming through fatty acid transport protein 1 (FATP1) regulates macrophage inflammatory potential and adipose inflammation. Mol. Metab. 2016, 5, 506-526. [CrossRef]

19. Larosa, D.F.; Orange, J.S. 1. Lymphocytes. J. Allergy Clin. Immunol. 2008, 121, S364-S369. [CrossRef] [PubMed]

20. Balyan, R.; Gautam, N.; Gascoigne, N.R.J. The ups and downs of metabolism during the lifespan of a T cell. Int. J. Mol. Sci. 2020, 21, 7972. [CrossRef] [PubMed]

21. Khalsa, J.K.; Chawla, A.S.; Prabhu, S.B.; Vats, M.; Dhar, A.; Dev, G.; Das, N.; Mukherjee, S.; Tanwar, S.; Banerjee, H.; et al Functionally significant metabolic differences between B and T lymphocyte lineages. Immunology 2019, 158, 104-120. [CrossRef] [PubMed]

22. Milasta, S.; Dillon, C.P.; Sturm, O.E.; Verbist, K.C.; Brewer, T.L.; Quarato, G.; Brown, S.A.; Frase, S.; Janke, L.J.; Perry, S.S.; et al. Apoptosis-inducing-factor-dependent mitochondrial function is required for T cell but not B cell function. Immunity 2016, 44, 88-102. [CrossRef]

23. Howie, D.; Ten Bokum, A.; Necula, A.S.; Cobbold, S.P.; Waldmann, H. The role of lipid metabolism in T lymphocyte differentiation and survival. Front. Immunol. 2018, 8, 1949. [CrossRef] [PubMed]

24. Hubler, M.J.; Kennedy, A.J. Role of lipids in the metabolism and activation of immune cells. J. Nutr. Biochem. 2016, $34,1-7$. [CrossRef] [PubMed]

25. Geltink, R.I.K.; Kyle, R.L.; Pearce, E.L. Unraveling the complex interplay between T cell metabolism and function. Annu. Rev. Immunol. 2018, 36, 461-488. [CrossRef] [PubMed]

26. Cretenet, G.; Clerc, I.; Matias, M.; Loisel, S.; Craveiro, M.; Oburoglu, L.; Kinet, S.; Mongellaz, C.; Dardalhon, V.; Taylor, N. Cell surface Glut1 levels distinguish human CD4 and CD8 T lymphocyte subsets with distinct effector functions. Sci. Rep. 2016, 6, 24129. [CrossRef] [PubMed]

27. Dang, E.V.; Barbi, J.; Yang, H.Y.; Jinasena, D.; Yu, H.; Zheng, Y.; Bordman, Z.; Fu, J.; Kim, Y.; Yen, H.R.; et al. Control of $\mathrm{T}(\mathrm{H}) 17 / \mathrm{T}(\mathrm{reg})$ balance by hypoxia-inducible factor 1. Cell 2011, 146, 772-784. [CrossRef]

28. Curi, R.; de Siqueira Mendes, R.; de Campos Crispin, L.A.; Norata, G.D.; Sampaio, S.C.; Newsholme, P. A past and present overview of macrophage metabolism and functional outcomes. Clin. Sci. 2017, 131, 1329-1342. [CrossRef]

29. Freemerman, A.J.; Johnson, A.R.; Sacks, G.N.; Milner, J.J.; Kirk, E.L.; Troester, M.A.; Macintyre, A.N.; Goraksha-Hicks, P.; Rathmell, J.C.; Makowski, L. Metabolic reprogramming of macrophages: Glucose transporter 1 (GLUT1)-mediated glucose metabolism drives a proinflammatory phenotype. J. Biol. Chem. 2014, 289, 7884-7896. [CrossRef] [PubMed]

30. Williams, N.C.; O'Neill, L.A.J. A role for the Krebs Cycle intermediate citrate in metabolic reprogramming in innate immunity and inflammation. Front. Immunol. 2018, 9, 141. [CrossRef] [PubMed]

31. Batista-Gonzalez, A.; Vidal, R.; Criollo, A.; Carreño, L.J. New Insights on the role of lipid metabolism in the metabolic reprogramming of macrophages. Front. Immunol. 2020, 10. [CrossRef] 
32. Castoldi, A.; Monteiro, L.B.; van Teijlingen Bakker, N.; Sanin, D.E.; Rana, N.; Corrado, M.; Cameron, A.M.; Hassler, F.; Matsushita, M.; Caputa, G.; et al. Triacylglycerol synthesis enhances macrophage inflammatory function. Nat. Commun. 2020, 11, 4107. [CrossRef] [PubMed]

33. Lefere, S.; Tacke, F. Macrophages in obesity and non-alcoholic fatty liver disease: Crosstalk with metabolism. JHEP Rep. 2019, 1, 30-43. [CrossRef]

34. Nomura, M.; Liu, J.; Rovira, I.I.; Gonzalez-Hurtado, E.; Lee, J.; Wolfgang, M.J.; Finkel, T. Fatty acid oxidation in macrophage polarization. Nat. Immunol. 2016, 17, 216-217. [CrossRef] [PubMed]

35. Xu, R.; Wang, S.; Li, W.; Liu, Z.; Tang, J.; Tang, X. Activation of peroxisome proliferator-activated receptor-gamma by a 12/15-lipoxygenase product of arachidonic acid: A possible neuroprotective effect in the brain after experimental intracerebral hemorrhage. J. Neurosurg. 2017, 127, 522-531. [CrossRef]

36. He, J.; Hong, B.; Bian, M.; Jin, H.; Chen, J.; Shao, J.; Zhang, F.; Zheng, S. Docosahexaenoic acid inhibits hepatic stellate cell activation to attenuate liver fibrosis in a PPARgamma-dependent manner. Int. Immunopharmacol. 2019, 75, 105816. [CrossRef]

37. Korbecki, J.; Bajdak-Rusinek, K. The effect of palmitic acid on inflammatory response in macrophages: An overview of molecular mechanisms. Inflamm. Res. 2019, 68, 915-932. [CrossRef]

38. Yang, W.; Chen, X.; Liu, Y.; Chen, M.; Jiang, X.; Shen, T.; Li, Q.; Yang, Y.; Ling, W. N-3 polyunsaturated fatty acids increase hepatic fibroblast growth factor 21 sensitivity via a PPAR-gamma-beta-klotho pathway. Mol. Nutr. Food Res. 2017, 61. [CrossRef]

39. Bouhlel, M.A.; Derudas, B.; Rigamonti, E.; Dievart, R.; Brozek, J.; Haulon, S.; Zawadzki, C.; Jude, B.; Torpier, G.; Marx, N.; et al. PPARgamma activation primes human monocytes into alternative M2 macrophages with anti-inflammatory properties. Cell Metab. 2007, 6, 137-143. [CrossRef]

40. Silveira, L.S.; Biondo, L.A.; de Souza Teixeira, A.A.; de Lima Junior, E.A.; Castoldi, A.; Camara, N.O.S.; Festuccia, W.T.; Rosa-Neto, J.C.; Lira, F.S. Macrophage immunophenotype but not anti-inflammatory profile is modulated by peroxisome proliferator-activated receptor gamma (PPARgamma) in exercised obese mice. Exerc. Immunol. Rev. 2020, 26, 10-22.

41. Varga, T.; Mounier, R.; Patsalos, A.; Gogolak, P.; Peloquin, M.; Horvath, A.; Pap, A.; Daniel, B.; Nagy, G.; Pintye, E.; et al. Macrophage PPARgamma, a lipid activated transcription factor controls the growth factor GDF3 and skeletal muscle regeneration. Immunity 2016, 45, 1038-1051. [CrossRef]

42. Gianfrancesco, M.A.; Dehairs, J.; L'Homme, L.; Herinckx, G.; Esser, N.; Jansen, O.; Habraken, Y.; Lassence, C.; Swinnen, J.V.; Rider, M.H.; et al. Saturated fatty acids induce NLRP3 activation in human macrophages through K(+) efflux resulting from phospholipid saturation and Na, K-ATPase disruption. Biochim. Biophys. Acta Mol. Cell Biol. Lipids 2019, 1864, 1017-1030. [CrossRef]

43. Poledne, R.; Malinska, H.; Kubatova, H.; Fronek, J.; Thieme, F.; Kauerova, S.; Lesna, I.K. Polarization of macrophages in human adipose tissue is related to the fatty acid spectrum in membrane phospholipids. Nutrients 2019, 12, 8. [CrossRef]

44. Lee, J.Y.; Sohn, K.H.; Rhee, S.H.; Hwang, D. Saturated fatty acids, but not unsaturated fatty acids, induce the expression of cyclooxygenase-2 mediated through Toll-like receptor 4. J. Biol. Chem. 2001, 276, 16683-16689. [CrossRef]

45. Staiger, H.; Staiger, K.; Stefan, N.; Wahl, H.G.; Machicao, F.; Kellerer, M.; Haring, H.U. Palmitate-induced interleukin-6 expression in human coronary artery endothelial cells. Diabetes 2004, 53, 3209-3216. [CrossRef]

46. Wong, S.W.; Kwon, M.J.; Choi, A.M.; Kim, H.P.; Nakahira, K.; Hwang, D.H. Fatty acids modulate Toll-like receptor 4 activation through regulation of receptor dimerization and recruitment into lipid rafts in a reactive oxygen species-dependent manner. $J$. Biol. Chem. 2009, 284, 27384-27392. [CrossRef]

47. Eguchi, K.; Manabe, I.; Oishi-Tanaka, Y.; Ohsugi, M.; Kono, N.; Ogata, F.; Yagi, N.; Ohto, U.; Kimoto, M.; Miyake, K.; et al. Saturated fatty acid and TLR signaling link beta cell dysfunction and islet inflammation. Cell Metab. 2012, 15, 518-533. [CrossRef]

48. Calder, P.C. Marine omega-3 fatty acids and inflammatory processes: Effects, mechanisms and clinical relevance. Biochim. Biophys. Acta Mol. Cell Biol. Lipids 2015, 1851, 469-484. [CrossRef] [PubMed]

49. Calder, P.C. n-3 PUFA and inflammation: From membrane to nucleus and from bench to bedside. Proc. Nutr. Soc. 2020, 79, 404-416. [CrossRef] [PubMed]

50. Chan, K.L.; Pillon, N.J.; Sivaloganathan, D.M.; Costford, S.R.; Liu, Z.; Theret, M.; Chazaud, B.; Klip, A. palmitoleate reverses high fat-induced proinflammatory macrophage polarization via AMP-activated protein kinase (AMPK). J. Biol. Chem. 2015, 290, 16979-16988. [CrossRef]

51. Souza, C.O.; Teixeira, A.A.S.; Biondo, L.A.; Silveira, L.S.; Calder, P.C.; Rosa Neto, J.C. Palmitoleic acid reduces the inflammation in LPS-stimulated macrophages by inhibition of NFKB, independently of PPARs. Clin. Exp. Pharmacol. Physiol. 2017, 44, 566-575. [CrossRef] [PubMed]

52. Souza, C.O.; Teixeira, A.A.S.; Biondo, L.A.; Silveira, L.S.; de Souza Breda, C.N.; Braga, T.T.; Camara, N.O.S.; Belchior, T.; Festuccia, W.T.; Diniz, T.A.; et al. Palmitoleic acid reduces high fat diet-induced liver inflammation by promoting PPAR-gammaindependent M2a polarization of myeloid cells. Biochim. Biophys. Acta Mol. Cell Biol. Lipids 2020, 1865, 158776. [CrossRef] [PubMed]

53. Kalugotla, G.; He, L.; Weber, K.J.; Daemen, S.; Reller, A.; Razani, B.; Schilling, J.D. Frontline Science: Acyl-CoA synthetase 1 exacerbates lipotoxic inflammasome activation in primary macrophages. J. Leukoc. Biol. 2019, 106, 803-814. [CrossRef] [PubMed]

54. Chen, Y.; Yang, M.; Huang, W.; Chen, W.; Zhao, Y.; Schulte, M.L.; Volberding, P.; Gerbec, Z.; Zimmermann, M.T.; Zeighami, A.; et al. Mitochondrial metabolic reprogramming by CD36 signaling drives macrophage inflammatory responses. Circ. Res. 2019, 125, 1087-1102. [CrossRef] 
55. Montenegro-Burke, J.R.; Sutton, J.A.; Rogers, L.M.; Milne, G.L.; McLean, J.A.; Aronoff, D.M. Lipid profiling of polarized human monocyte-derived macrophages. Prostaglandins Other Lipid Mediat. 2016, 127, 1-8. [CrossRef]

56. Ghanim, H.; Aljada, A.; Hofmeyer, D.; Syed, T.; Mohanty, P.; Dandona, P. Circulating mononuclear cells in the obese are in a proinflammatory state. Circulation 2004, 110, 1564-1571. [CrossRef]

57. Zhao, N.; Wang, L.; Guo, N. alpha-Linolenic acid increases the G0/G1 switch gene 2 mRNA expression in peripheral blood mononuclear cells from obese patients: A pilot study. Lipids Health Dis. 2016, 15, 36. [CrossRef]

58. Dangardt, F.; Osika, W.; Chen, Y.; Nilsson, U.; Gan, L.M.; Gronowitz, E.; Strandvik, B.; Friberg, P. Omega-3 fatty acid supplementation improves vascular function and reduces inflammation in obese adolescents. Atherosclerosis 2010, 212, 580-585. [CrossRef]

59. Lau, Y.C.C.; Ding, J.A.; Simental, A.; Mirzoyan, H.; Lee, W.; Diamante, G.; Cely, I.; Tran, M.; Morselli, M.; Dang, J.; et al. Omega-3 fatty acids increase OXPHOS energy for immune therapy of Alzheimer disease patients. FASEB J. 2020, 34, 9982-9994. [CrossRef]

60. Davanso, M.R.; Crisma, A.R.; Braga, T.T.; Masi, L.N.; do Amaral, C.L.; Leal, V.N.C.; de Lima, D.S.; Patente, T.A.; Barbuto, J.A.; Correa-Giannella, M.L.; et al. Macrophage inflammatory state in type 1 diabetes: Triggered by NLRP3/iNOS pathway and attenuated by docosahexaenoic acid (DHA). Clin. Sci. 2020. [CrossRef]

61. Han, L.; Zhou, R.; Niu, J.; McNutt, M.A.; Wang, P.; Tong, T. SIRT1 is regulated by a PPAR\{gamma\}-SIRT1 negative feedback loop associated with senescence. Nucleic Acids Res. 2010, 38, 7458-7471. [CrossRef] [PubMed]

62. Laine, P.S.; Schwartz, E.A.; Wang, Y.; Zhang, W.Y.; Karnik, S.K.; Musi, N.; Reaven, P.D. Palmitic acid induces IP-10 expression in human macrophages via NF-kappaB activation. Biochem. Biophys. Res. Commun. 2007, 358, 150-155. [CrossRef]

63. Tam, T.H.; Chan, K.L.; Boroumand, P.; Liu, Z.; Brozinick, J.T.; Bui, H.H.; Roth, K.; Wakefield, C.B.; Penuela, S.; Bilan, P.J.; et al. Nucleotides released from palmitate-activated murine macrophages attract neutrophils. J. Biol. Chem. 2020, $295,4902-4911$. [CrossRef]

64. Cullberg, K.B.; Larsen, J.O.; Pedersen, S.B.; Richelsen, B. Effects of LPS and dietary free fatty acids on MCP-1 in 3T3-L1 adipocytes and macrophages in vitro. Nutr. Diabetes 2014, 4, e113. [CrossRef]

65. Wang, S.; Wu, D.; Lamon-Fava, S.; Matthan, N.R.; Honda, K.L.; Lichtenstein, A.H. In vitro fatty acid enrichment of macrophages alters inflammatory response and net cholesterol accumulation. Br. J. Nutr. 2009, 102, 497-501. [CrossRef] [PubMed]

66. Baker, E.J.; Valenzuela, C.A.; De Souza, C.O.; Yaqoob, P.; Miles, E.A.; Calder, P.C. Comparative anti-inflammatory effects of plantand marine-derived omega-3 fatty acids explored in an endothelial cell line. Biochim. Biophys. Acta Mol. Cell Biol. Lipids 2020, 1865, 158662. [CrossRef]

67. Adolph, S.; Fuhrmann, H.; Schumann, J. Unsaturated fatty acids promote the phagocytosis of P. aeruginosa and R. equi by RAW264.7 macrophages. Curr. Microbiol. 2012, 65, 649-655. [CrossRef] [PubMed]

68. Pauls, S.D.; Rodway, L.A.; Winter, T.; Taylor, C.G.; Zahradka, P.; Aukema, H.M. Alpha-linolenic acid enhances the phagocytic and secretory functions of alternatively activated macrophages in part via changes to the oxylipin profile. Int. J. Biochem. Cell Biol. 2020, 119, 105662. [CrossRef] [PubMed]

69. Calder, P.C.; Bond, J.A.; Harvey, D.J.; Gordon, S.; Newsholme, E.A. Uptake and incorporation of saturated and unsaturated fatty acids into macrophage lipids and their effect upon macrophage adhesion and phagocytosis. Biochem. J. 1990, 269, 807-814. [CrossRef]

70. Baker, E.J.; Yusof, M.H.; Yaqoob, P.; Miles, E.A.; Calder, P.C. Omega-3 fatty acids and leukocyte-endothelium adhesion: Novel anti-atherosclerotic actions. Mol. Asp. Med. 2018, 64, 169-181. [CrossRef]

71. Rocha, D.M.; Caldas, A.P.; Oliveira, L.L.; Bressan, J.; Hermsdorff, H.H. Saturated fatty acids trigger TLR4-mediated inflammatory response. Atherosclerosis 2016, 244, 211-215. [CrossRef]

72. Rowe, D.C.; McGettrick, A.F.; Latz, E.; Monks, B.G.; Gay, N.J.; Yamamoto, M.; Akira, S.; O’Neill, L.A.; Fitzgerald, K.A.; Golenbock, D.T. The myristoylation of TRIF-related adaptor molecule is essential for Toll-like receptor 4 signal transduction. Proc. Natl. Acad. Sci. USA 2006, 103, 6299-6304. [CrossRef] [PubMed]

73. Kim, Y.C.; Lee, S.E.; Kim, S.K.; Jang, H.D.; Hwang, I.; Jin, S.; Hong, E.B.; Jang, K.S.; Kim, H.S. Toll-like receptor mediated inflammation requires FASN-dependent MYD88 palmitoylation. Nat. Chem. Biol. 2019, 15, 907-916. [CrossRef]

74. Carroll, R.G.; Zaslona, Z.; Galvan-Pena, S.; Koppe, E.L.; Sevin, D.C.; Angiari, S.; Triantafilou, M.; Triantafilou, K.; Modis, L.K.; O'Neill, L.A. An unexpected link between fatty acid synthase and cholesterol synthesis in proinflammatory macrophage activation. J. Biol. Chem. 2018, 293, 5509-5521. [CrossRef] [PubMed]

75. Wei, X.; Song, H.; Yin, L.; Rizzo, M.G.; Sidhu, R.; Covey, D.F.; Ory, D.S.; Semenkovich, C.F. Fatty acid synthesis configures the plasma membrane for inflammation in diabetes. Nature 2016, 539, 294-298. [CrossRef] [PubMed]

76. Schaefer, M.B.; Schaefer, C.A.; Schifferings, S.; Kuhlmann, C.R.; Urban, A.; Benscheid, U.; Fischer, T.; Hecker, M.; Morty, R.E.; Vadasz, I.; et al. N-3 vs. n-6 fatty acids differentially influence calcium signalling and adhesion of inflammatory activated monocytes: Impact of lipid rafts. Inflamm. Res. 2016, 65, 881-894. [CrossRef] [PubMed]

77. Seim, G.L.; John, S.V.; Fan, J. Metabolomic and lipidomic analysis of bone marrow derived macrophages. Biol. Protoc. 2020, 10, e3693. [CrossRef]

78. Al-Rashed, F.; Ahmad, Z.; Thomas, R.; Melhem, M.; Snider, A.J.; Obeid, L.M.; Al-Mulla, F.; Hannun, Y.A.; Ahmad, R. Neutral sphingomyelinase 2 regulates inflammatory responses in monocytes/macrophages induced by TNF-alpha. Sci. Rep. 2020, 10, 16802. [CrossRef] 
79. Ardawi, M.S.; Majzoub, M.F.; Kateilah, S.M.; Newsholme, E.A. Maximal activity of phosphate-dependent glutaminase and glutamine metabolism in septic rats. J. Lab. Clin. Med. 1991, 118, 26-32.

80. Burns, C.P.; Welshman, I.R.; Spector, A.A. Differences in free fatty acid and glucose metabolism of human blood neutrophils and lymphocytes. Blood 1976, 47, 431-437. [CrossRef]

81. Anel, A.; Naval, J.; Gonzalez, B.; Torres, J.M.; Mishal, Z.; Uriel, J.; Pineiro, A. Fatty acid metabolism in human lymphocytes. I. Time-course changes in fatty acid composition and membrane fluidity during blastic transformation of peripheral blood lymphocytes. Biochim. Biophys. Acta 1990, 1044, 323-331. [CrossRef]

82. Calder, P.C.; Yaqoob, P.; Harvey, D.J.; Watts, A.; Newsholme, E.A. Incorporation of fatty acids by concanavalin A-stimulated lymphocytes and the effect on fatty acid composition and membrane fluidity. Biochem. J. 1994, 300, 509-518. [CrossRef]

83. Maciolek, J.A.; Pasternak, J.A.; Wilson, H.L. Metabolism of activated T lymphocytes. Curr. Opin. Immunol. 2014, 27, 60-74. [CrossRef]

84. El Hage, A.; Dormond, O. Combining mTOR inhibitors and T cell-based immunotherapies in cancer treatment. Cancers 2021, 13, 1359. [CrossRef]

85. Lee, J.; Walsh, M.C.; Hoehn, K.L.; James, D.E.; Wherry, E.J.; Choi, Y. Regulator of fatty acid metabolism, acetyl coenzyme a carboxylase 1, controls T cell immunity. J. Immunol. 2014, 192, 3190-3199. [CrossRef]

86. Muroski, M.E.; Miska, J.; Chang, A.L.; Zhang, P.; Rashidi, A.; Moore, H.; Lopez-Rosas, A.; Han, Y.; Lesniak, M.S. Fatty acid uptake in T cell subsets using a quantum dot fatty acid conjugate. Sci. Rep. 2017, 7, 5790. [CrossRef]

87. Buck, M.D.; O'Sullivan, D.; Klein Geltink, R.I.; Curtis, J.D.; Chang, C.H.; Sanin, D.E.; Qiu, J.; Kretz, O.; Braas, D.; van der Windt, G.J.; et al. Mitochondrial dynamics controls T cell fate through metabolic programming. Cell 2016, 166, 63-76. [CrossRef]

88. Alarcon-Barrera, J.C.; von Hegedus, J.H.; Brouwers, H.; Steenvoorden, E.; Ioan-Facsinay, A.; Mayboroda, O.A.; Ondo-Mendez, A.; Giera, M. Lipid metabolism of leukocytes in the unstimulated and activated states. Anal. Bioanal. Chem. 2020, 412, $2353-2363$. [CrossRef] [PubMed]

89. Garcia-Cao, I.; Song, M.S.; Hobbs, R.M.; Laurent, G.; Giorgi, C.; de Boer, V.C.; Anastasiou, D.; Ito, K.; Sasaki, A.T.; Rameh, L.; et al. Systemic elevation of PTEN induces a tumor-suppressive metabolic state. Cell 2012, 149, 49-62. [CrossRef] [PubMed]

90. Cluxton, D.; Petrasca, A.; Moran, B.; Fletcher, J.M. Differential regulation of human Treg and Th17 cells by fatty acid synthesis and glycolysis. Front. Immunol. 2019, 10, 115. [CrossRef]

91. Berod, L.; Friedrich, C.; Nandan, A.; Freitag, J.; Hagemann, S.; Harmrolfs, K.; Sandouk, A.; Hesse, C.; Castro, C.N.; Bahre, H.; et al. De novo fatty acid synthesis controls the fate between regulatory T and T helper 17 cells. Nat. Med. 2014, 20, 1327-1333. [CrossRef]

92. Nicholas, D.A.; Proctor, E.A.; Agrawal, M.; Belkina, A.C.; Van Nostrand, S.C.; Panneerseelan-Bharath, L.; Jones, A.R.t.; Raval, F.; Ip, B.C.; Zhu, M.; et al. Fatty acid metabolites combine with reduced beta oxidation to activate Th17 inflammation in human type 2 diabetes. Cell Metab. 2019, 30, 447-461e445. [CrossRef]

93. Hradilkova, K.; Maschmeyer, P.; Westendorf, K.; Schliemann, H.; Husak, O.; von Stuckrad, A.S.L.; Kallinich, T.; Minden, K.; Durek, P.; Grun, J.R.; et al. Regulation of Fatty acid oxidation by twist 1 in the metabolic adaptation of T helper lymphocytes to chronic inflammation. Arthritis Rheumatol. 2019, 71, 1756-1765. [CrossRef]

94. Fu, G.; Guy, C.S.; Chapman, N.M.; Palacios, G.; Wei, J.; Zhou, P.; Long, L.; Wang, Y.D.; Qian, C.; Dhungana, Y.; et al. Metabolic control of TFH cells and humoral immunity by phosphatidylethanolamine. Nature 2021. [CrossRef]

95. Frauwirth, K.A.; Riley, J.L.; Harris, M.H.; Parry, R.V.; Rathmell, J.C.; Plas, D.R.; Elstrom, R.L.; June, C.H.; Thompson, C.B. The CD28 signaling pathway regulates glucose metabolism. Immunity 2002, 16, 769-777. [CrossRef]

96. Wang, R.; Dillon, C.P.; Shi, L.Z.; Milasta, S.; Carter, R.; Finkelstein, D.; McCormick, L.L.; Fitzgerald, P.; Chi, H.; Munger, J.; et al. The transcription factor Myc controls metabolic reprogramming upon T lymphocyte activation. Immunity 2011, 35, 871-882. [CrossRef]

97. Pearce, E.L.; Walsh, M.C.; Cejas, P.J.; Harms, G.M.; Shen, H.; Wang, L.S.; Jones, R.G.; Choi, Y. Enhancing CD8 T-cell memory by modulating fatty acid metabolism. Nature 2009, 460, 103-107. [CrossRef]

98. Patsoukis, N.; Bardhan, K.; Chatterjee, P.; Sari, D.; Liu, B.; Bell, L.N.; Karoly, E.D.; Freeman, G.J.; Petkova, V.; Seth, P.; et al. PD-1 alters T-cell metabolic reprogramming by inhibiting glycolysis and promoting lipolysis and fatty acid oxidation. Nat. Commun. 2015, 6, 6692. [CrossRef]

99. Blagih, J.; Coulombe, F.; Vincent, E.E.; Dupuy, F.; Galicia-Vazquez, G.; Yurchenko, E.; Raissi, T.C.; van der Windt, G.J.; Viollet, B.; Pearce, E.L.; et al. The energy sensor AMPK regulates T cell metabolic adaptation and effector responses in vivo. Immunity 2015, 42, 41-54. [CrossRef]

100. Sukumar, M.; Liu, J.; Ji, Y.; Subramanian, M.; Crompton, J.G.; Yu, Z.; Roychoudhuri, R.; Palmer, D.C.; Muranski, P.; Karoly, E.D.; et al. Inhibiting glycolytic metabolism enhances CD8+ T cell memory and antitumor function. J. Clin. Investig. 2013, 123, 4479-4488. [CrossRef]

101. van der Windt, G.J.; Everts, B.; Chang, C.H.; Curtis, J.D.; Freitas, T.C.; Amiel, E.; Pearce, E.J.; Pearce, E.L. Mitochondrial respiratory capacity is a critical regulator of CD8+ T cell memory development. Immunity 2012, 36, 68-78. [CrossRef]

102. Gupta, S.S.; Wang, J.; Chen, M. Metabolic Reprogramming in CD8(+) T cells during acute viral infections. Front. Immunol. 2020, 11, 1013. [CrossRef]

103. Pan, Y.; Tian, T.; Park, C.O.; Lofftus, S.Y.; Mei, S.; Liu, X.; Luo, C.; O’Malley, J.T.; Gehad, A.; Teague, J.E.; et al. Survival of tissue-resident memory $T$ cells requires exogenous lipid uptake and metabolism. Nature 2017, 543, 252-256. [CrossRef] 
104. van der Windt, G.J.; O'Sullivan, D.; Everts, B.; Huang, S.C.; Buck, M.D.; Curtis, J.D.; Chang, C.H.; Smith, A.M.; Ai, T.; Faubert, B.; et al. CD8 memory T cells have a bioenergetic advantage that underlies their rapid recall ability. Proc. Natl. Acad. Sci. USA 2013, 110, 14336-14341. [CrossRef]

105. Akkaya, M.; Traba, J.; Roesler, A.S.; Miozzo, P.; Akkaya, B.; Theall, B.P.; Sohn, H.; Pena, M.; Smelkinson, M.; Kabat, J.; et al. Second signals rescue B cells from activation-induced mitochondrial dysfunction and death. Nat. Immunol. 2018, 19, 871-884. [CrossRef] [PubMed]

106. Caro-Maldonado, A.; Wang, R.; Nichols, A.G.; Kuraoka, M.; Milasta, S.; Sun, L.D.; Gavin, A.L.; Abel, E.D.; Kelsoe, G.; Green, D.R.; et al. Metabolic reprogramming is required for antibody production that is suppressed in anergic but exaggerated in chronically BAFF-exposed B cells. J. Immunol. 2014, 192, 3626. [CrossRef] [PubMed]

107. Brookens, S.K.; Boothby, M.R. AMPK Metabolism in the B lineage modulates humoral responses. Immunometabolism 2021, 3. [CrossRef]

108. Chen, M.; Kodali, S.; Jang, A.; Kuai, L.; Wang, J. Requirement for autophagy in the long-term persistence but not initial formation of memory B cells. J. Immunol. 2015, 194, 2607-2615. [CrossRef] [PubMed]

109. Hauser, A.E.; Höpken, U.E. Chapter 12-B Cell Localization and Migration in Health and Disease. In Molecular Biology of B Cells, 2nd ed.; Alt, F.W., Honjo, T., Radbruch, A., Reth, M., Eds.; Academic Press: London, UK, 2015; pp. $187-214$.

110. Herrera, E.; Martinez, A.C.; Blasco, M.A. Impaired germinal center reaction in mice with short telomeres. EMBO J. 2000, 19, 472-481. [CrossRef]

111. Jellusova, J.; Cato, M.H.; Apgar, J.R.; Ramezani-Rad, P.; Leung, C.R.; Chen, C.; Richardson, A.D.; Conner, E.M.; Benschop, R.J.; Woodgett, J.R.; et al. Gsk3 is a metabolic checkpoint regulator in B cells. Nat. Immunol. 2017, 18, 303-312. [CrossRef]

112. Weisel, F.J.; Mullett, S.J.; Elsner, R.A.; Menk, A.V.; Trivedi, N.; Luo, W.; Wikenheiser, D.; Hawse, W.F.; Chikina, M.; Smita, S.; et al. Germinal center B cells selectively oxidize fatty acids for energy while conducting minimal glycolysis. Nat. Immunol. 2020, 21, 331-342. [CrossRef]

113. Cucchi, D.; Camacho-Muñoz, D.; Certo, M.; Niven, J.; Smith, J.; Nicolaou, A.; Mauro, C. Omega-3 polyunsaturated fatty acids impinge on CD4+ T cell motility and adipose tissue distribution via direct and lipid mediator-dependent effects. Cardiovasc. Res. 2019, 116, 1006-1020. [CrossRef]

114. Geyeregger, R.; Zeyda, M.; Zlabinger, G.J.; Waldhausl, W.; Stulnig, T.M. Polyunsaturated fatty acids interfere with formation of the immunological synapse. J. Leukoc. Biol. 2005, 77, 680-688. [CrossRef]

115. Shaikh, S.R.; Mitchell, D.; Carroll, E.; Li, M.; Schneck, J.; Edidin, M. Differential effects of a saturated and a monounsaturated fatty acid on MHC class I antigen presentation. Scand. J. Immunol. 2008, 68, 30-42. [CrossRef]

116. Passos, M.E.; Alves, H.H.; Momesso, C.M.; Faria, F.G.; Murata, G.; Cury-Boaventura, M.F.; Hatanaka, E.; Massao-Hirabara, S.; Gorjao, R. Differential effects of palmitoleic acid on human lymphocyte proliferation and function. Lipids Health Dis. 2016, 15, 217. [CrossRef] [PubMed]

117. Seike, T.; Mizukoshi, E.; Yamada, K.; Okada, H.; Kitahara, M.; Yamashita, T.; Arai, K.; Terashima, T.; Iida, N.; Fushimi, K.; et al. Fatty acid-driven modifications in T-cell profiles in non-alcoholic fatty liver disease patients. J. Gastroenterol. 2020, 55, 701-711. [CrossRef] [PubMed]

118. Balmer, M.L.; Ma, E.H.; Bantug, G.R.; Grahlert, J.; Pfister, S.; Glatter, T.; Jauch, A.; Dimeloe, S.; Slack, E.; Dehio, P.; et al. Memory CD8(+) T cells require increased concentrations of acetate induced by stress for optimal function. Immunity 2016, 44, 1312-1324 [CrossRef]

119. Qiu, J.; Villa, M.; Sanin, D.E.; Buck, M.D.; O’Sullivan, D.; Ching, R.; Matsushita, M.; Grzes, K.M.; Winkler, F.; Chang, C.H.; et al. Acetate promotes $\mathrm{T}$ cell effector function during glucose restriction. Cell Rep. 2019, 27, 2063-2074. [CrossRef] [PubMed]

120. Yang, W.; Yu, T.; Huang, X.; Bilotta, A.J.; Xu, L.; Lu, Y.; Sun, J.; Pan, F.; Zhou, J.; Zhang, W.; et al. Intestinal microbiota-derived short-chain fatty acids regulation of immune cell IL-22 production and gut immunity. Nat. Commun. 2020, 11, 4457. [CrossRef]

121. Park, M.; Cho, K.A.; Kim, Y.H.; Lee, K.H.; Woo, S.Y. Lymphatic endothelial cells promote T lymphocyte migration into lymph nodes under hyperlipidemic conditions. Biochem. Biophys. Res. Commun. 2020, 525, 786-792. [CrossRef]

122. O'Rourke, R.W.; Kay, T.; Scholz, M.H.; Diggs, B.; Jobe, B.A.; Lewinsohn, D.M.; Bakke, A.C. Alterations in T-cell subset frequency in peripheral blood in obesity. Obes. Surg. 2005, 15, 1463-1468. [CrossRef] [PubMed]

123. Van der Weerd, K.; Dik, W.A.; Schrijver, B.; Schweitzer, D.H.; Langerak, A.W.; Drexhage, H.A.; Kiewiet, R.M.; van Aken, M.O.; van Huisstede, A.; van Dongen, J.J.; et al. Morbidly obese human subjects have increased peripheral blood CD4+ T cells with skewing toward a Treg- and Th2-dominated phenotype. Diabetes 2012, 61, 401-408. [CrossRef] [PubMed]

124. Guesdon, W.; Kosaraju, R.; Brophy, P.; Clark, A.; Dillingham, S.; Aziz, S.; Moyer, F.; Willson, K.; Dick, J.R.; Patil, S.P.; et al. Effects of fish oils on ex vivo B-cell responses of obese subjects upon BCR/TLR stimulation: A pilot study. J. Nutr. Biochem. 2018, 53, 72-80. [CrossRef] [PubMed]

125. Calder, P.C. The effects of fatty acids on lymphocyte functions. Braz. J. Med Biol. Res. 1993, 26, 901-917. [PubMed] 